\title{
Increased risk of tick-borne diseases with climate and environmental changes
}

\author{
C Bouchard ${ }^{1,2 *}$, A Dibernardo ${ }^{3}, \mathrm{~J} \mathrm{Koffi}^{2,4}, \mathrm{H}$ Wood $^{3}$, PA Leighton ${ }^{2}$, LR Lindsay ${ }^{3}$
}

\begin{abstract}
Climate warming and other environmental changes have contributed to the expansion of the range of several tick species into higher latitudes in North America. As temperatures increase in Canada, the environment becomes more suitable for ticks and the season suitable for tick activity lengthens, so tick-borne diseases are likely to become more common in Canada. In addition to Lyme disease, four other tick-borne diseases (TBDs) have started to emerge and are likely to increase: Anaplasmosis; Babesiosis; Powassan virus; and Borrelia miyamotoi disease. Increased temperature increases the survival and activity period of ticks, increases the range of both reservoir and tick hosts (e.g. mice and deer) and increases the duration of the season when people may be exposed to ticks. Other ticks and TBDs may spread into Canada as the climate changes. The public health strategies to mitigate the impact of all TBDs include surveillance to detect current and emerging TBDs, and public health actions to prevent infections by modifying environmental and social-behavioral risk factors through increasing public awareness. Clinical care strategies include patient education, early detection, laboratory testing, and treatment.
\end{abstract}

Suggested citation: Bouchard C, Dibernardo A, Koffi J, Wood H, Leighton PA, Lindsay LR. Increased risk of tick-borne diseases with climate and environmental changes. Can Commun Dis Rep 2019; 45(4):81-9.

https://doi.org/10.14745/ccdr.v45i04a02

Keywords: climate change, tick-borne disease, Anaplasmosis, Babesiosis, Anaplasma phagocytophilum, Babesia microti, Powassan virus, Borrelia miyamotoi

\section{Introduction}

Ticks transmit a wide diversity of bacterial, viral and protozoan pathogens in many tropical and temperate regions of the world (1). Of particular concern in North America are the blacklegged ticks that transmit Borrelia burgdorferi, the bacterium that causes Lyme disease (LD) in southern parts of central and eastern Canada (2). It is now widely acknowledged that the increase in temperature associated with climate change has contributed to a general increase in the number, types, level of activity and geographical distribution of ticks in North America (1-11) and has directly contributed to the northward spread of blacklegged ticks and LD into Canada (12). As a result, LD has emerged in Canada and the number of reported cases of Lyme disease continues to rise $(13,14)$.

The purpose of this overview is to summarize the climate and other environmental changes affecting the risk of ticks and tick-borne diseases (TBDs), identify the ticks and TBDs that are occurring or that may spread into Canada and describe the public health and clinical strategies for the management of ticks and TBDs.

\section{The effect of climate and other environmental changes}

Climate and other environmental changes are expected to increase the risk of ticks and TBDs in a number of ways. The prevalence, activity and range of a variety of ticks and the pathogens they carry are expected to increase. This is due to changing weather that also causes an increase in the range of animal reproductive and reservoir hosts. Humans are also expected to change their behaviours as the climate changes; bringing both animal hosts and humans into annual contact with ticks over a longer season $(15,16)$. Tick and host habitats can also be affected by factors other than climate.
This work is licensed under a Creative Commons Attribution 4.0 International License.

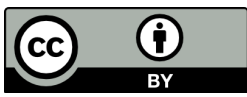

Affiliations

${ }^{1}$ Public Health Risk Sciences Division, National Microbiology Laboratory, Public Health Agency of Canada, St. Hyacinthe, QC

${ }^{2}$ Groupe de recherche en épidémiologie des zoonoses et santé publique (GREZOSP), Faculté de médecine vétérinaire (FMV), Université de Montréal, St. Hyacinthe, QC

3 Zoonotic Diseases and Special Pathogens, National Microbiology Laboratory, Public Health Agency of Canada, Winnipeg, MB

${ }^{4}$ Center for Food-borne, Environmental and Zoonotic Infectious Diseases, Public Health Agency of Canada, Ottawa, ON

*Correspondence: catherine. bouchard@canada.ca 
Increase in number, activity and range of ticks

In Canada, there has been a documented increase in temperature, changes in rainfall patterns and extreme weather events (extreme heat and rainfall) associated with climate change (17). The key climate change effect that has influenced ticks and tick-borne pathogens in Canada, however, is increasing temperature (5). Rising temperature has led to improved conditions for survival and reproduction of ticks and faster development leading to an acceleration of the tick lifecycle (5) that has:

- Increased tick abundance, where tick populations already occur (8)

- Enabled tick populations to spread to higher latitudes (18-23)

- Increased tick activity and questing behavior resulting in longer seasonal activity $(5,24)$

Prolonged extremes values of temperature (high or low), low humidity and intense rainfall could adversely affect tick development by reducing their activity and increasing their mortality rate (5). These changes in temperature are expected to have less of an effect on ticks than on mosquitoes because of the tick's ability to find refuge in their woodland habitats (5).

Increase in number, activity and range of hosts Animals that are reservoir and reproduction hosts are crucial for the transmission cycle of tick-borne pathogens and the tick lifecycle, respectively. The reservoir host is the source of the pathogen for the immature stages of the ticks (25). For most TBDs, the main reservoir hosts are wild rodents, including mice. The reproduction hosts are the source of blood-meals essential for adult female ticks to reproduce. In contrast, the most common reproduction host are deer $(26,27)$. Climate change affects both the reproduction hosts and the reservoir hosts involved in the tick lifecycle and spread of TBDs, respectively (Figure 1). Increasing temperatures will expand the distribution range of both rodents and deer $(28,29)$ as well as their abundance and activity $(3,29)$.

\section{Increase in human exposure to ticks}

Most ticks are active from the time that the snow melts in the spring until the reappearance of the snow cover in the fall. Typically, questing for a host begins when ambient air temperatures are $4-10^{\circ} \mathrm{C}$. As a result of climate change, people may resume outdoor activity earlier in the spring and maintain it longer in the fall. With the increase in length of exposure to tick habitat, combined with an extended season of tick activity, there is an increased likelihood of tick exposure. In contrast, during consecutive hot and dry summer days (heat waves), both outdoor (human) activity and tick activity would likely be reduced. Overall, the risk of climate change on human exposure is more closely related to shorter winters, rather than extreme heat summer weather events.

Figure 1: Weather and climate drivers that favor ticks' lifecycle and increase risk to humans

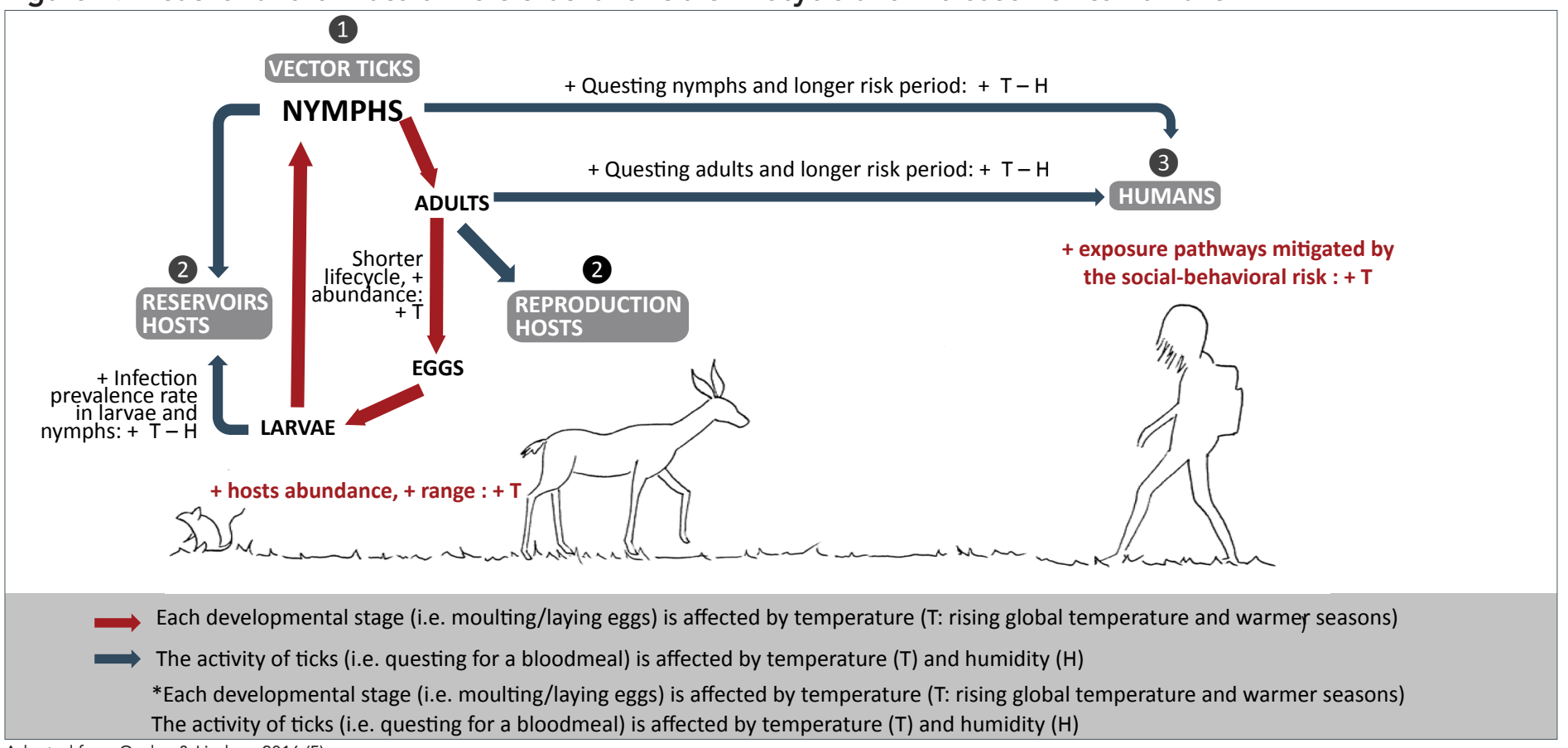

Adapted from Ogden \& Lindsey, 2016 (5) 
The main risk groups for TBDs are those:

- Who are engaged in recreational or occupational outdoor activities (e.g. hunting, fishing, hiking, camping, gardening, mushroom or berries picking, dog walking, forestry and farming) in or near endemic areas

- Whose primary or secondary residence is located in or near endemic areas

- Who are either very young (5-9 years of age) or older (55 years of age and older) (30)

\section{Impact of other environmental changes}

All tick species have preferred/optimal biomes and environmental conditions that, in part, determine their geographic distribution and consequently the areas of risk for humans (31). Microhabitat features, such as soil characteristics, are critical for tick survival and the successful establishment of new tick populations (32-34). Modifications in habitat characteristics, in parallel with climate change, such as habitat fragmentation, loss of biodiversity, resource availability and land use, affect the dynamics of ticks, their animal hosts and the exposure of ticks to humans $(29,35)$. As an historical example, LD emerged in the United States (US) in the 1970s as a consequence of the reforestation of farmland and the consequent increase in the deer populations, which allowed the expansion of the Ixodes scapularis tick populations that were carrying $B$. burgdorferi (3).

\section{Increased tick-borne diseases in Canada}

Lyme disease is the most common and well-known tick-borne disease in Canada. At least four other (non-LD) TBDs are emerging in Canada and these are anticipated to increase due to the effects of climate change: Anaplasmosis; Babesiosis; Powassan virus; and Borrelia miyamotoi disease.

\section{Lyme disease}

Lyme disease is caused by B. burgdorferi, which can infect $I$. scapularis ticks in central and eastern Canada and I. pacificus ticks in British Columbia. It has been reported in every province from British Columbia to Prince Edward Island (PEI) and it is well-known that LD is on the rise (13). Lyme disease typically presents with an erythema migrans rash and non-specific symptoms such as fatigue, fever, headache and muscle and joint pains and, if left untreated, can become a multisystem disease. Lyme disease is rarely fatal but deaths linked to Lyme carditis have recently been reported (36).

\section{Anaplasmosis}

Anaplasmosis is caused by the bacterium Anaplasma phagocytophilum, which is spread by I. scapularis in eastern and central Canada (37) and I. pacificus in British Columbia, and human or animal cases have been reported in most provinces where the ticks occur (38). Clinically, people can have asymptomatic $A$. phagocytophilum infections, but most frequently have non-specific symptoms (e.g. fever, headache and muscle aches). The case fatality rate is less than 1\% (39).

\section{Babesiosis}

Babesiosis is caused by a malaria-like protozoan Babesia microti, which causes a Lyme-like disease. To date, human cases have been reported only in Manitoba (9) but the pathogen has been detected in I. scapularis ticks in Manitoba, Ontario, Quebec and New Brunswick (40). The case fatality rate in the US is $2 \%-5 \%$ (39).

\section{Powassan virus}

Powassan virus was first detected in Powassan, Ontario and can be found in a number of different tick species. Presentation of Powassan infection can vary greatly, from asymptomatic infections to fatal encephalitis cases (case fatality rate of 10\%) (41). Although many of the tick-associated pathogens require an extended period of tick feeding prior to transmission, Powassan virus can be transmitted within 15-30 minutes of tick attachment (42). Two lineages have been identified in vector ticks: Lineage I identified in Ixodes in Ontario, Quebec, New Brunswick and PEl; and Lineage II identified in I. scapularis from Manitoba, Ontario and Nova Scotia (7).

\section{Borrelia miyamotoi disease}

Borrelia miyamotoi was first identified in 2013 in Canada and this pathogen has been found in I. scapularis and I. pacificus ticks (10). Borrelia miyamotoi disease is similar to LD signs but without a rash. Rarely, it can cause meningoencephalitis.

\section{Rarer tick-borne diseases that may emerge}

Dermacentor spp. ticks are common and can transmit the bacterium Rickettsia rickettsii, which causes Rocky Mountain spotted fever. Typically, fever, severe headache, myalgia, nausea and rash can occur 5 to 10 days after the infection. The estimated case fatality rate is around $5 \%-10 \%(39,43)$. Other spotted fever group rickettsial species may also be transmitted by Dermacentor ticks in Canada.

Colorado tick fever virus is currently found in some of the Western US states, and there have been a few reported cases in Saskatchewan and Alberta. It is spread by a tick common in western Canada: Dermacentor andersoni (or Rocky Mountain wood tick). Other Borrelia species have been found in the upper western and Midwestern states that have spread to a few cases in British Columbia and Ontario. Some Ehrlichia species have been found in the Southeastern and South Central US but there have been no human cases detected in Canada.

Table 1 summarizes the human pathogens associated with various tick species in Canada and those in the US that may spread north into Canada with climate change, identifies when a pathogens was first identified as a cause of TBD, its principal reservoir host species, current or historical geographic distribution and whether it has been detected in ticks, humans or other animals. 
Table 1: Tick-borne pathogens that are present in or may spread to Canada

\begin{tabular}{|c|c|c|c|c|c|c|c|c|c|}
\hline \multirow{2}{*}{ Pathogen } & \multirow{2}{*}{$\begin{array}{l}\text { Year } \\
\text { of ID }\end{array}$} & \multirow{2}{*}{$\begin{array}{l}\text { Principal tick } \\
\text { vector(s) }\end{array}$} & \multirow{2}{*}{$\begin{array}{c}\text { Principal } \\
\text { reservoir } \\
\text { host species }\end{array}$} & \multicolumn{2}{|c|}{ Geographic distribution $^{a}$} & \multirow{2}{*}{$\begin{array}{c}\text { Nationally } \\
\text { notifiable }\end{array}$} & \multicolumn{3}{|c|}{ Detection in Canada } \\
\hline & & & & Canada & US & & Tick & Human & Animal \\
\hline $\begin{array}{l}\text { Anaplasma } \\
\text { phagocytophilum }\end{array}$ & 1994 & $\begin{array}{l}\text { Ixodes } \\
\text { scapularis, } \\
\text { Ixodes pacificus }\end{array}$ & Rodents & $\begin{array}{l}\mathrm{BC}, \mathrm{AB}, \mathrm{SK}, \mathrm{MB}, \\
\mathrm{ON}, \mathrm{QC}, \mathrm{NB}, \mathrm{NL}, \\
\text { NS, PEI }\end{array}$ & $\begin{array}{l}\text { Upper MW and NE } \\
\text { states }\end{array}$ & No & Yes & Yes & Yes \\
\hline Babesia microti & 1970 & $\begin{array}{l}\text { Ixodes } \\
\text { scapularis }\end{array}$ & Mice & $\begin{array}{l}\text { MB, ON, QC, NB, } \\
\text { NS }\end{array}$ & $\begin{array}{l}\text { NE and upper MW } \\
\text { states }\end{array}$ & No & Yes & Yes & Yes \\
\hline $\begin{array}{l}\text { Borrelia } \\
\text { burgdorferi }\end{array}$ & 1982 & $\begin{array}{l}\text { Ixodes } \\
\text { scapularis, } \\
\text { Ixodes pacificus }\end{array}$ & Rodents & $\begin{array}{l}\mathrm{BC}, \mathrm{AB}, \mathrm{SK}, \mathrm{MB} \\
\mathrm{ON}, \mathrm{QC}, \mathrm{NB}, \mathrm{NS}, \\
\mathrm{NL}, \mathrm{PEI}\end{array}$ & $\begin{array}{l}\text { NE and upper MW } \\
\text { states }\end{array}$ & Yes & Yes & Yes & Yes \\
\hline Borrelia hermsii & 1935 & $\begin{array}{l}\text { Ornithodoros } \\
\text { hermsi }\end{array}$ & $\begin{array}{l}\text { Rodents and } \\
\text { rabbits }\end{array}$ & $B C$ & Western states & No & --- & Yes & --- \\
\hline $\begin{array}{l}\text { Borrelia mayonii/ } \\
\text { Borrelia mayonii- } \\
\text { like }\end{array}$ & 2014 & $\begin{array}{l}\text { Ixodes } \\
\text { scapularis/ } \\
\text { Ixodes angustus }\end{array}$ & Rodents & ON, BC & $\begin{array}{l}\text { Upper MW states: } \\
\text { Minnesota and } \\
\text { Wisconsin }\end{array}$ & No & Yes & --- & Yes \\
\hline $\begin{array}{l}\text { Borrelia } \\
\text { miyamotoi }\end{array}$ & 2013 & $\begin{array}{l}\text { lxodes } \\
\text { scapularis, } \\
\text { Ixodes pacificus }\end{array}$ & Mice & $\begin{array}{l}\mathrm{BC}, \mathrm{AB}, \mathrm{MB}, \mathrm{ON}, \\
\mathrm{OC}, \mathrm{NB}, \mathrm{NS}, \mathrm{NL}, \\
\mathrm{PEI}\end{array}$ & $\begin{array}{l}\text { Upper MW, NE, } \\
\text { and the Mid- } \\
\text { Atlantic states }\end{array}$ & No & Yes & No & --- \\
\hline $\begin{array}{l}\text { Colorado tick } \\
\text { fever virus }\end{array}$ & 1946 & $\begin{array}{l}\text { Dermacentor } \\
\text { andersoni }\end{array}$ & $\begin{array}{l}\text { Golden } \\
\text { mantled } \\
\text { squirrels, deer } \\
\text { mice and } \\
\text { rabbits }\end{array}$ & $S K, A B$ & $\begin{array}{l}\text { Western states: } \\
\text { Colorado, } \\
\text { Utah, Montana, } \\
\text { Wyoming }\end{array}$ & No & No & Yes & --- \\
\hline $\begin{array}{l}\text { Ehrlichia } \\
\text { chaffeensis }\end{array}$ & 1987 & $\begin{array}{l}\text { Amblyomma } \\
\text { americanum }\end{array}$ & $\begin{array}{l}\text { White-tailed } \\
\text { deer }\end{array}$ & --- & $\begin{array}{l}\text { Southeastern and } \\
\text { South Central } \\
\text { states }\end{array}$ & No & No & No & --- \\
\hline Ehrlichia ewingii & 1999 & $\begin{array}{l}\text { Amblyomma } \\
\text { americanum }\end{array}$ & $\begin{array}{l}\text { White-tailed } \\
\text { deer }\end{array}$ & --- & $\begin{array}{l}\text { Southeastern and } \\
\text { South Central } \\
\text { states }\end{array}$ & No & --- & --- & --- \\
\hline $\begin{array}{l}\text { Ehrlichia muris- } \\
\text { like agent }\end{array}$ & 2011 & $\begin{array}{l}\text { Ixodes } \\
\text { scapularis/ } \\
\text { Ixodes muris }\end{array}$ & Mice & $\mathrm{MB}$ & Upper MW states & No & Yes & -- & --- \\
\hline $\begin{array}{l}\text { Francisella } \\
\text { tularensis }\end{array}$ & 1924 & $\begin{array}{l}\text { Dermacentor } \\
\text { variabilis, } \\
\text { Dermacentor } \\
\text { andersoni, } \\
\text { Amblyomma } \\
\text { americanum }\end{array}$ & $\begin{array}{l}\text { Rabbits, hares, } \\
\text { and rodents }\end{array}$ & Canada wide & All states & Yes & Yes & Yes & Yes \\
\hline Heartland virus & 2012 & $\begin{array}{l}\text { Amblyomma } \\
\text { americanum }\end{array}$ & $\begin{array}{l}\text { White-tailed } \\
\text { deer }\end{array}$ & --- & $\begin{array}{l}\text { MW and South } \\
\text { states }\end{array}$ & No & No & -- & --- \\
\hline $\begin{array}{l}\text { Lineage I } \\
\text { Powassan virus }\end{array}$ & 1963 & $\begin{array}{l}\text { Ixodes cookei, } \\
\text { Ixodes marxi, } \\
\text { Ixodes } \\
\text { spinipalpis }\end{array}$ & $\begin{array}{l}\text { Small and } \\
\text { medium-sized } \\
\text { woodland } \\
\text { mammals } \\
\text { (woodchucks) }\end{array}$ & ON, QC, NB, PEI & $\begin{array}{l}\text { NE states and } \\
\text { Great Lakes region }\end{array}$ & No & Yes & Yes & Yes \\
\hline $\begin{array}{l}\text { Lineage II } \\
\text { Powassan virus }\end{array}$ & 2001 & $\begin{array}{l}\text { Ixodes } \\
\text { scapularis, } \\
\text { Dermacentor } \\
\text { andersoni }\end{array}$ & Mice & $\mathrm{MB}, \mathrm{ON}, \mathrm{NS}$ & $\begin{array}{l}\text { NE and upper MW } \\
\text { states }\end{array}$ & No & Yes & --- & --- \\
\hline $\begin{array}{l}\text { Rickettsia } \\
\text { rickettsii }\end{array}$ & 1909 & $\begin{array}{l}\text { Dermacentor } \\
\text { variabilis, } \\
\text { Dermacentor } \\
\text { andersoni, } \\
\text { Rhipicephalus } \\
\text { sanguineus }\end{array}$ & $\begin{array}{l}\text { Variety of wild } \\
\text { mammals } \\
\text { including } \\
\text { rodents }\end{array}$ & $\begin{array}{l}B C, A B, S K, O N, \\
N S\end{array}$ & $\begin{array}{l}\text { Eastern, Central, } \\
\text { Western and } \\
\text { Southwestern } \\
\text { states }\end{array}$ & No & $Y^{b}{ }^{b}$ & $Y_{e s}^{b}$ & Yes \\
\hline
\end{tabular}




\section{Public health and clinical strategies}

A key public health activity to address TBDs is surveillance. Detection of ticks, reporting of human cases and maintenance of accurate information on the overall risk of human exposure to ticks and their associated tick-borne pathogens are necessary to inform clinical care and public health action (45). Currently, active and passive tick surveillance programs in Canada are focused mainly on I. scapularis, the main vector of LD. Surveillance efforts are centered on areas where LD did not previously exist or areas where it may not be recognized. As other TBDs emerge, the need for broader surveillance will follow.

Once the risk areas are identified geographically, education and awareness of risk and prevention strategies targeted to people who are at high risk of exposure is central to effective disease prevention. Due to the recent changing range of ticks, and hence the pathogens that they carry, this is especially important in newly-identified at-risk populations because knowledge and perception of risk are currently low (46-48).

Health care providers play an important role in prevention education by informing their patients about the ways to reduce their exposure to vector ticks when travelling, both within Canada and abroad. Risk prevention strategies include applying personal protective measures and making tick checks routine after exposure in high risk areas. Clinicians are also critical for the early detection, obtaining laboratory confirmation and management of these illnesses. Public health efforts include surveillance, environmental modifications and management strategies for ticks and host animals.

Building capacity and awareness is important. For most TBD, early diagnosis and treatment are the most effective ways to reduce serious clinical outcomes. It is suspected that not all cases are currently being detected, reported and/or confirmed. TBDs have substantial clinical overlap (such as fever, headaches, myalgia, and arthralgia). In anticipation of an increase in the types of TBDs in Canada, clinicians need to be aware that if a patient presents with LD-like symptoms and has a negative test for LD, he/she could still have a TBD and further laboratory testing may be indicated. The absence of a rash should not rule out a TBD.

\section{Discussion}

In Canada, an ongoing process of emergence and spread of ticks and TBDs is anticipated in localities where climate, weather and habitat favor ticks and transmission cycles of tick-borne pathogens. It is important to note, however, that the relationship between tick-borne diseases and climate is not linear. There are modifiable risk factors that will affect the incidence of TBDs in Canada. These modifiable risk factors include both environmental and human factors. Environmental modification is not minor: one study indicated that removal of leaf litter (detritus and dead leaves) led to a $72 \%-100 \%$ reduction in ticks (49). Knowledge and risk perception about LD have been associated with the degree of adoption of personal tick bite preventive behaviors in Canada $(47,48)$; however, other factors need to be considered. Human population growth, movement and behavior, economics and politics have also been associated with differential rates of human exposure to ticks and the risk of transmission of TBDs $(15,16,46)$. Rapid changes in socio-economic factors concurrent with the climate and other environmental changes underscore the importance of viewing the rising incidence and spread of TBDs as a complex socio-ecological problem, not driven just by climate or other environmental changes, and the need to quantify their relative contributions to the overall burden of disease.

The key climate change drivers and the social-behavioral factors that interact and determine the health outcomes from TBDs are noted in Figure 2. One of the challenges going forward will be to appreciate that the rising incidence and geographical spread of TBDs is a complex socio-ecological problem. This also provides opportunities for new intervention strategies. A few studies have addressed the human social-behavioral risk factors associated with TBDs in the context of adaptation to climate change (46$48,50)$. More sociological studies are needed. Psycho-behavioral studies are also needed to assess how the knowledge that climate change will increase ticks and associated TBDs may be a motivating factor. Finally, it will be important to look for resilience factors or the adaptive capacity of the individuals or communities at risk to minimize the risk of TBDs.

Figure 2: Key climate changes, ecological factors and social-behavioral risks that affect the acquisition of tickborne diseases

KEY CLIMATE CHANGE DRIVERS AFFECTINGS TICK-BORNE DISEASES

- Temperature

Precipitation (i.e. intensity and frequency)

- Seasonal weather
ECOLOGICAL RISK

CHANGING PATTERN OF :

VECTOR TICKS

- Abundance (i.e. population size,

pathogen infection rate)

- Activity (i.e. questing behaviors or

changing seasonal peak/duration)

- Geographic distribution (i.e. range)

RESERVOIR/REPRODUCTION HOSTS

- Abundance (i.e. population size)

- Activity (e.g. daily movement)

- Geographic distribution (i.e. range)

HABITAT

- Landscape change
SOCIAL-BEHAVIORAL RISK

HUMANS

- Outdoor activity

- Type and duration of activities at risk

Shifting months at risk

(e.g. early warm spring)

Social determinants of health

(e.g. personal protection) and risk perception toward TBDs

Socio-economic risk factors

Landscape design (e.g. proximity to "woodlands or green areas")
- Knowledge, preventive behavior

\section{HEALTH OUTCOMES}

Tick-borne diseases after exposure to ticks (i.e. higher likelihood of transmission)

Adapted from Beard et al. 2016 (50) 


\section{Conclusion}

The expanding geographic range of tick vector species, and the diseases they carry, creates a moving target for clinicians and public health authorities. The clear link with climate change is an opportunity to increase the motivation to address current and emerging TBDs in Canada. While work on addressing climate change will continue more broadly, there is an opportunity to work on other modifiable risk factors that affect TBDs in Canada, appreciating that this is a complex socio-ecological challenge.

\section{Authors' statement}

The authors would like to thank the anonymous reviewers and editorial staff of Canadian Communicable Disease Report who providing helpful suggestions that greatly improved the quality of this manuscript.

CB - Conceptualization, writing: original draft, review and editing

AD - Writing: original draft, review and editing

JK - Writing: original draft, review and editing

HW - Writing: original draft, review and editing

$P L$ - Writing: original draft, review and editing

LRL-Writing: original draft, review and editing

\section{Conflict of interest}

None.

\section{Funding}

This work was supported by the Public Health Agency of Canada.
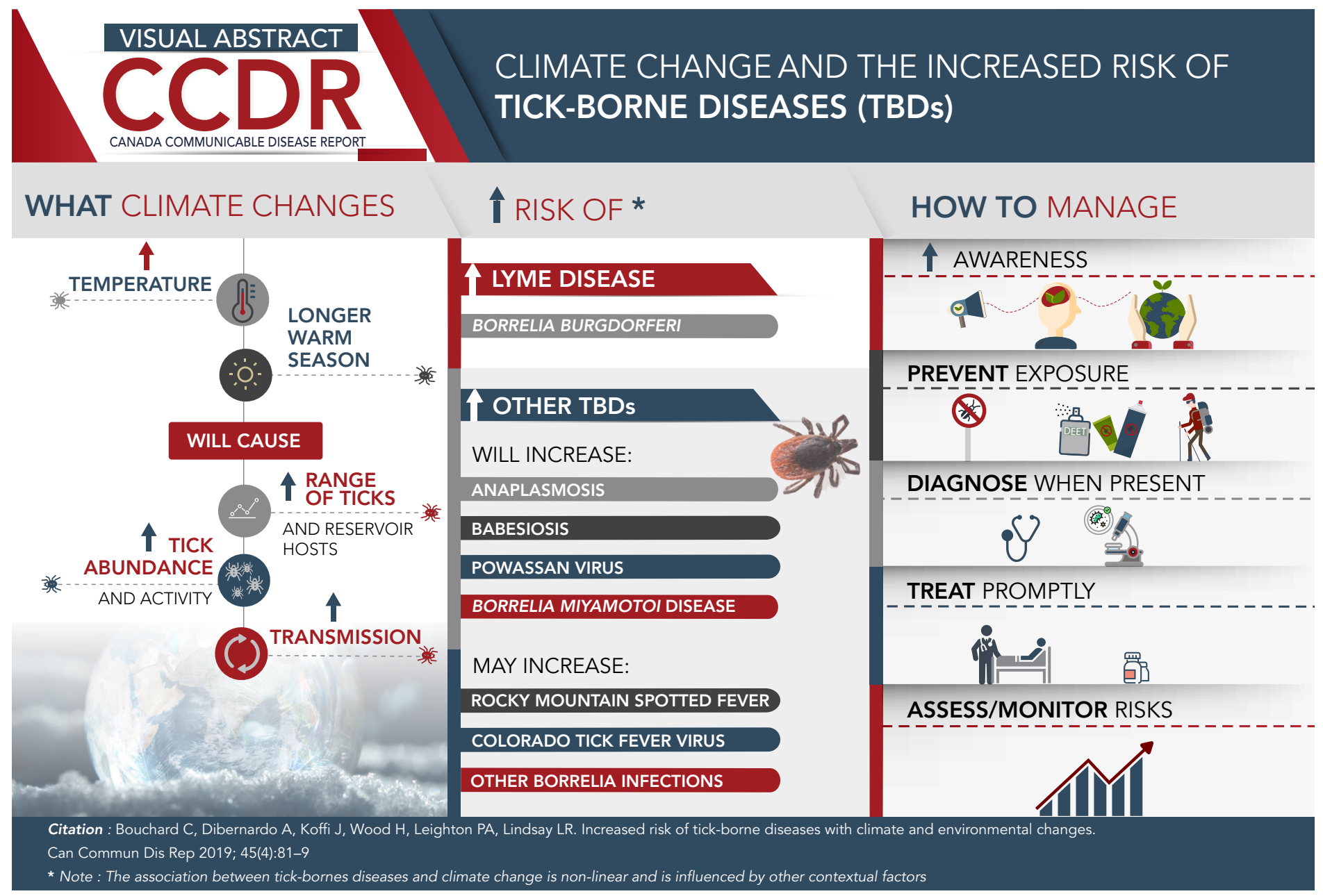


\section{References}

1. Sonenshine DE. Range expansion of tick disease vectors in North America: implications for spread of tick-borne disease. Int J Environ Res Public Health 2018 Mar;15(3):E478. DOI PubMed

2. Bouchard C, Leonard E, Koffi JK, Pelcat Y, Peregrine A, Chilton N, Rochon K, Lysyk T, Lindsay LR, Ogden NH. The increasing risk of Lyme disease in Canada. Can Vet J 2015 Jul;56(7):693-9. PubMed

3. Kilpatrick AM, Dobson AD, Levi T, Salkeld DJ, Swei A, Ginsberg HS, Kjemtrup A, Padgett KA, Jensen PM, Fish D, Ogden NH, Diuk-Wasser MA. Lyme disease ecology in a changing world: consensus, uncertainty and critical gaps for improving control. Philos Trans R Soc Lond B Biol Sci 2017 Jun;372(1722):20160117. DOI PubMed

4. Werden L, Lindsay LR, Barker IK, Bowman J, Gonzales EK, Jardine CM. Prevalence of Anaplasma phagocytophilum and Babesia microti in Ixodes scapularis from a newly established Lyme disease endemic area, the Thousand Islands region of Ontario, Canada. Vector Borne Zoonotic Dis 2015 Oct;15(10):627-9. DOl PubMed

5. Ogden $\mathrm{NH}$, Lindsay LR. Effects of climate and climate change on vectors and vector-borne diseases: ticks are different. Trends Parasitol 2016 Aug;32(8):646-56. DOI PubMed

6. Eisen RJ, Kugeler KJ, Eisen L, Beard CB, Paddock CD. Tick-borne zoonoses in the United States: persistent and emerging threats to human health. ILAR J 2017 Dec;58(3):319-35. DOl PubMed

7. Corrin T, Greig J, Harding S, Young I, Mascarenhas M, Waddell LA. Powassan virus, a scoping review of the global evidence. 2018;65(6):595-624. DOI

8. Gasmi S, Bouchard C, Ogden NH, Adam-Poupart A, Pelcat Y, Rees EE, Milord F, Leighton PA, Lindsay RL, Koffi JK, Thivierge K. Evidence for increasing densities and geographic ranges of tick species of public health significance other than Ixodes scapularis in Québec, Canada. PLoS One 2018 Aug;13(8):e0201924. DOI PubMed

9. Bullard JM, Ahsanuddin AN, Perry AM, Lindsay LR, Iranpour M, Dibernardo A, Van Caeseele PG. The first case of locally acquired tick-borne Babesia microti infection in Canada. Can J Infect Dis Med Microbiol 2014 Nov-Dec;25(6):e87-9. DOI PubMed

10. Dibernardo A, Cote T, Ogden NH, Lindsay LR. The prevalence of Borrelia miyamotoi infection, and co-infections with other Borrelia spp. in Ixodes scapularis ticks collected in Canada. Parasit Vectors 2014 Apr;7:183. DOI PubMed

11. Ogden NH, Radojevic M, Wu X, Duvvuri VR, Leighton PA, Wu J. Estimated effects of projected climate change on the basic reproductive number of the Lyme disease vector Ixodes scapularis. Environ Health Perspect 2014 Jun;122(6):631-8. DOI PubMed

12. Ebi KL, Ogden NH, Semenza JC, Woodward A. Detecting and Attributing Health Burdens to Climate Change. Environ Health Perspect 2017 Aug;125(8):085004. DOl PubMed

13. Gasmi S, Ogden NH, Lindsay LR, Burns $S$, Fleming $S_{,}$ Badcock J, Hanan S, Gaulin C, Leblanc MA, Russell C, Nelder M, Hobbs L, Graham-Derham S, Lachance L, Scott AN, Galanis E, Koffi JK. Surveillance for Lyme disease in Canada: 2009-2015. Can Commun Dis Rep 2017 Oct;43(10):194-9. DOI PubMed

14. Nelder MP, Wijayasri S, Russell CB, Johnson KO, Marchand-Austin A, Cronin K et al. The continued rise of Lyme disease in Ontario, Canada: 2017. Can Commun Dis Rep 2018;44(10):231-6. DO।

15. Randolph SE. Fauna, climate and politics: possible causes for the recent increases in tick-borne zoonoses. Arch Pediatr 2004 Oct;11(10):1282-5. DOl PubMed

16. Randolph SE. Is expert opinion enough? A critical assessment of the evidence for potential impacts of climate change on tick-borne diseases. Anim Health Res Rev 2013 Dec;14(2):133-7. DOl PubMed

17. Warren FJ, Lemmen DS. (2014): Synthesis; in Canada in a Changing Climate: Sector Perspectives on Impacts and Adaptation, (ed.) F.J. Warren and D.S. Lemmen; Government of Canada, Ottawa, ON, p. 1-18.

18. Bouchard C, Beauchamp G, Nguon S, Trudel L, Milord F, Lindsay LR, Bélanger D, Ogden NH. Associations between Ixodes scapularis ticks and small mammal hosts in a newly endemic zone in southeastern Canada: implications for Borrelia burgdorferi transmission. Ticks Tick Borne Dis 2011 Dec;2(4):183-90. DOl PubMed

19. Brownstein JS, Holford TR, Fish D. Effect of climate change on Lyme disease risk in North America. EcoHealth 2005 Mar;2(1):38-46. DOI PubMed

20. Ogden NH, Barker IK, Francis CM, Heagy A, Lindsay LR, Hobson KA. How far north are migrant birds transporting the tick Ixodes scapularis in Canada? Insights from stable hydrogen isotope analyses of feathers. Ticks Tick Borne Dis 2015 Sep;6(6):715-20. DOI PubMed

21. Ogden NH, Bigras-Poulin $\mathrm{M}, \mathrm{O}^{\prime}$ Callaghan $\mathrm{CJ}$, Barker IK, Lindsay LR, Maarouf A, Smoyer-Tomic KE, Waltner-Toews $D$, Charron D. A dynamic population model to investigate effects of climate on geographic range and seasonality of the tick Ixodes scapularis. Int J Parasitol 2005 Apr;35(4):375-89. DOI PubMed

22. Clow KM, Leighton PA, Ogden NH, Lindsay LR, Michel P, Pearl DL, Jardine CM. Northward range expansion of Ixodes scapularis evident over a short timescale in Ontario, Canada. PLoS One 2017 Dec;12(12):e0189393. DOI PubMed 
23. Ogden NH, Bouchard C, Kurtenbach K, Margos G, Lindsay LR, Trudel L, Nguon S, Milord F. Active and passive surveillance and phylogenetic analysis of Borrelia burgdorferi elucidate the process of Lyme disease risk emergence in Canada. Environ Health Perspect 2010 Jul;118(7):909-14. DOI PubMed

24. Gilbert L, Aungier J, Tomkins JL. Climate of origin affects tick (Ixodes ricinus) host-seeking behavior in response to temperature: implications for resilience to climate change? Ecol Evol 2014 Apr;4(7):1186-98. DOI PubMed

25. Bouchard C, Beauchamp G, Leighton PA, Lindsay R, Bélanger D, Ogden NH. Does high biodiversity reduce the risk of Lyme disease invasion? Parasit Vectors $2013 \mathrm{Jul} ; 6: 195$. DOI PubMed

26. Bouchard C, Leighton PA, Beauchamp G, Nguon S, Trudel L, Milord F, Lindsay LR, Bélanger D, Ogden NH. Harvested white-tailed deer as sentinel hosts for early establishing Ixodes scapularis populations and risk from vector-borne zoonoses in southeastern Canada. J Med Entomol 2013 Mar;50(2):384-93. DOl PubMed

27. Levi T, Kilpatrick AM, Mangel M, Wilmers CC. Deer, predators, and the emergence of Lyme disease. Proc Natl Acad Sci USA 2012 Jul;109(27):10942-7. DOI PubMed

28. Roy-Dufresne E, Logan T, Simon JA, Chmura GL, Millien V. Poleward expansion of the white-footed mouse (Peromyscus leucopus) under climate change: implications for the spread of lyme disease. PLoS One 2013 Nov;8(11):e80724. DOI PubMed

29. Simon JA, Marrotte RR, Desrosiers N, Fiset J, Gaitan J, Gonzalez A, Koffi JK, Lapointe FJ, Leighton PA, Lindsay LR, Logan T, Milord F, Ogden NH, Rogic A, Roy-Dufresne E, Suter D, Tessier N, Millien V. Climate change and habitat fragmentation drive the occurrence of Borrelia burgdorferi, the agent of Lyme disease, at the northeastern limit of its distribution. Evol Appl 2014 Aug;7(7):750-64. DOI PubMed

30. Bacon RM, Kugeler KJ, Mead PS; Centers for Disease Control and Prevention (CDC). Surveillance for Lyme disease-United States, 1992-2006. MMWR Surveill Summ 2008 Oct;57(10):1-9. PubMed

31. Parola P, Paddock CD. Travel and tick-borne diseases: lyme disease and beyond. Travel Med Infect Dis 2018 Nov Dec;26:1-2. DOl PubMed

32. Estrada-Peña A, Ostfeld RS, Peterson AT, Poulin R, de la Fuente J. Effects of environmental change on zoonotic disease risk: an ecological primer. Trends Parasitol 2014 Apr;30(4):205-14. DOI PubMed

33. Lindsay LR, Barker IK, Surgeoner GA, McEwen SA, Gillespie TJ, Addison EM. Survival and development of the different life stages of Ixodes scapularis (Acari: Ixodidae) held within four habitats on Long Point, Ontario, Canada. J Med Entomol 1998 May;35(3):189-99. DOl PubMed
34. Guerra M, Walker E, Jones C, Paskewitz S, Cortinas MR, Stancil A, Beck L, Bobo M, Kitron U. Predicting the risk of Lyme disease: habitat suitability for Ixodes scapularis in the north central United States. Emerg Infect Dis 2002 Mar;8(3):289-97. PubMed

35. Brownstein JS, Skelly DK, Holford TR, Fish D. Forest fragmentation predicts local scale heterogeneity of Lyme disease risk. Oecologia 2005 Dec;146(3):469-75. DOI PubMed

36. Kugeler KJ, Griffith KS, Gould LH, Kochanek K, Delorey MJ, Biggerstaff BJ, Mead PS. A review of death certificates listing Lyme disease as a cause of death in the United States. Clin Infect Dis 2011 Feb;52(3):364-7. DOI PubMed

37. Krakowetz CN, Dibernardo A, Lindsay LR, Chilton NB. Two Anaplasma phagocytophilum strains in Ixodes scapularis ticks, Canada. Emerg Infect Dis 2014 Dec;20(12):2064-7. DOI PubMed

38. Edginton S, Guan TH, Evans G, Srivastava S. Human granulocytic anaplasmosis acquired from a blacklegged tick in Ontario. CMAJ 2018 Mar;190(12):E363-6. DOI PubMed

39. Biggs HM, Behravesh CB, Bradley KK, Dahlgren FS, Drexler NA, Dumler JS, Folk SM, Kato CY, Lash RR, Levin ML, Massung RF, Nadelman RB, Nicholson WL, Paddock CD, Pritt BS, Traeger MS. Diagnosis and management of tickborne Rickettsial diseases: rocky Mountain spotted fever and other spotted fever group Rickettsioses, Ehrlichioses, and Anaplasmosis - United States. MMWR Recomm Rep 2016 May;65(2):1-44. DOI PubMed

40. O'Brien SF, Delage G, Scalia V, Lindsay R, Bernier F, Dubuc S, Germain M, Pilot G, Yi QL, Fearon MA. Seroprevalence of Babesia microti infection in Canadian blood donors. Transfusion 2016 Jan;56(1):237-43. DOI PubMed

41. Artsob H. 1988. Powassan encephalitis. Pp. 29-49 in T.P. Monath (ed.), The arboviruses: epidemiology and ecology, Vol. 4. CRC Press, Boca Raton, Florida.

42. Ebel GD, Kramer LD. Short report: duration of tick attachment required for transmission of powassan virus by deer ticks. Am J Trop Med Hyg 2004 Sep;71(3):268-71. DOI PubMed

43. Ogden NH, Artsob H, Marogs G, Tsao J. (2014). Non-rickettsial tick-borne bacteria and the diseases they cause, in Biology of Ticks, Chapter 10, Vol. 2 2nd Edn. eds Sonenshine D. E., Roe R. M., editors. (New York, NY: Oxford University Press), 278-312.

44. Paddock CD, Lane RS, Staples JE, Labruna MB. Changing Paradigms for Tick-borne Diseases in the Americas. Global Health Impacts of Vector-borne Diseases: Workshop Summary. Washington (DC): National Academies Press (US); 2016. p. A8. www.ncbi.nlm.nih.gov/books/NBK390439/

45. Beard CB. Lyme disease prevention and control - the way forward. Can Commun Dis Rep 2014 Mar;40(5):91-4. DOI PubMed 
46. Bouchard C, Aenishaenslin C, Rees EE, Koffi JK, Pelcat $Y$, Ripoche M, Milord F, Lindsay LR, Ogden NH, Leighton PA. Integrated social-behavioral and ecological risk maps to prioritize local public health responses to Lyme disease. Environ Health Perspect 2018 Apr;126(4):047008. DOI PubMed

47. Aenishaenslin C, Bouchard C, Koffi JK, Ogden NH. Exposure and preventive behaviours toward ticks and Lyme disease in Canada: results from a first national survey. Ticks Tick Borne Dis 2017 Jan;8(1):112-8. DOI PubMed
48. Aenishaenslin C, Bouchard C, Koffi JK, Pelcat Y, Ogden NH. Evidence of rapid changes in Lyme disease awareness in Canada. Ticks Tick Borne Dis 2016 Oct;7(6):1067-74. DOI PubMed

49. Schulze TL, Jordan RA, Hung RW. Suppression of subadult Ixodes scapularis (Acari: Ixodidae) following removal of leaf litter. J Med Entomol 1995 Sep;32(5):730-3. DOI PubMed

50. Beard CB, Eisen RJ, Barker CM, Garofalo JF, Hahn M, Hayden $\mathrm{M}$ et al. The Impacts of Climate Change on Human Health in the United States: A Scientific Assessment. U.S. Global Change Research Program, Washington, DC, 2016. Chapter 5, Vectorborne Diseases; p.129-56. DOI 